OPEN ACCESS

Edited by:

Tian Li,

Nankai University, China

Reviewed by:

Peidong Su,

Research Center

for Eco-Environmental Sciences

(CAS), China

Hanxiang Li,

Chongqing University, China

*Correspondence:

Xiao Huang

huangxiao901231@126.com

Weiyan Duan

duanweiyan@hebau.edu.cn

Specialty section:

This article was submitted to

Microbiotechnology,

a section of the journal

Frontiers in Microbiology

Received: 18 December 2021

Accepted: 26 January 2022

Published: 02 March 2022

Citation:

Sun $P$, Huang $X$, Xing $Y$, Dong $W$,

Yu J, Bai J and Duan W (2022) Immobilization of Ochrobactrum sp. on Biochar/Clay Composite Particle:

Optimization of Preparation

and Performance for Nitrogen

Removal.

Front. Microbiol. 13:838836

doi: 10.3389/fmicb.2022.838836

\section{Immobilization of Ochrobactrum sp. on Biochar/Clay Composite Particle: Optimization of Preparation and Performance for Nitrogen Removal}

\author{
Pengfei Sun ${ }^{1,2,3}$, Xiao Huang ${ }^{4 *}$, Yixiao Xing ${ }^{4}$, Wenlong Dong ${ }^{5}$, Jianghua Yu ${ }^{4}$, Jie Bai ${ }^{6}$ and \\ Weiyan Duan ${ }^{7 *}$ \\ ${ }^{1}$ Ministry of Natural Resources, Fourth Institute of Oceanography, Beihai, China, ${ }^{2}$ Key Laboratory of Tropical Marine \\ Ecosystem and Bioresource, Ministry of Natural Resources, Beihai, China, ${ }^{3}$ Guangxi Beibu Gulf Key Laboratory of Marine \\ Resources, Environment and Sustainable Development, Beihai, China, ${ }^{4}$ Jiangsu Key Laboratory of Atmospheric \\ Environment Monitoring and Pollution Control, Collaborative Innovation Center of Atmospheric Environment and Equipment \\ Technology, School of Environmental Science and Engineering, Naniing University of Information Science and Technology, \\ Nanjing, China, ${ }^{5}$ Shandong Marine Forecast and Hazard Mitigation Service, Qingdao, China, ${ }^{6}$ College of Environmental \\ Science and Engineering, Ocean University of China, Qingdao, China, ${ }^{7}$ Ocean College of Hebei Agricultural University, \\ Qinhuangdao, China
}

The objective of this study was to prepare biochar/clay composite particle (BCCP) as carrier to immobilize Ochrobactrum sp. to degrade ammonia nitrogen $\left(\mathrm{NH}_{4}{ }^{+}-\mathrm{N}\right)$, and the effects of calcined program and immobilizing material were investigated. Results reflected that the parameters were as follows: calcined temperature $400^{\circ} \mathrm{C}$, heating rate $20^{\circ} \mathrm{C} \mathrm{min}-1$, and holding time $2 \mathrm{~h}$, and the adsorption capacity could reach $0.492 \mathrm{mg}$ $\mathrm{g}^{-1}$. Sodium alginate/polyvinyl alcohol, as embedding material, jointed with $\mathrm{NH}_{4}{ }^{+}-\mathrm{N}$ adsorption process and then degraded by Ochrobactrum sp. with $79.39 \%$ degradation efficiency at $168 \mathrm{~h}$. Immobilizing Ochrobactrum sp. could protect strain from high salt concentration to achieve the exceeding degradation efficiency than free bacteria, but could not block the impact of low temperature.

Keywords: biochar/clay composite particle, calcined temperature, ammonia-oxidizing bacteria, immobilization, Ochrobactrum sp.

\section{INTRODUCTION}

Liaohe Estuary Wetland (LEW) owned the functions of regulating climate, alleviating flood peak, providing habitat for wildlife, and protecting biodiversity, and crab farming is the main industry there (Lin et al., 2016). Hence, serious ammonia nitrogen $\left(\mathrm{NH}_{4}{ }^{+}-\mathrm{N}\right)$ pollution was caused by excessive crab feed and contributed to the eutrophication in LEW (Hina et al., 2015).

A kind of biochar/clay composite particle (BCCP) absorbing $\mathrm{NH}_{4}{ }^{+}-\mathrm{N}$ was prepared with waste biochar and clay in LEW by previous studies and demonstrated that its removal effectively related to the ratio of materials, and the dosage of crosslinking agent and pore-forming agent (Huang et al., 2020). In fact, the calcined temperature and program of BCCP are also the key parameters restricting and affecting its adsorption performance and adsorption capacity depending on the changing of adsorption site quantity and adsorption material structures (Mandal and Mayadevi, 2008; Feng et al., 2013; Sun et al., 2015). Lin et al. (2009) found that the phenol adsorption capacity by nano-hydroxyapatite powder from aqueous solution reduced obviously when it was calcined at 
high temperature. For $\mathrm{TiO}_{2}$, the organic moieties were destroyed by high calcination temperature and affected the adsorption performance (Feng et al., 2020). On the contrary, Yan et al. (2018) prepared porous diatomite microspheres with different calcined temperatures, and concluded that the production was amorphous at $800^{\circ} \mathrm{C}$ and crystallized into crystobalite at $1,000^{\circ} \mathrm{C}$. Nevertheless, whether a relationship between calcined temperature and $\mathrm{NH}_{4}{ }^{+}-\mathrm{N}$ adsorption capacity of BCCP exists or not needs to be further researched.

$\mathrm{NH}_{4}{ }^{+}-\mathrm{N}$ adsorption process is only the transfer of $\mathrm{NH}_{4}{ }^{+}$$\mathrm{N}$ without complete conversion by ammonia-oxidizing bacteria (AOB). For LEW, the harsh environmental conditions of low temperature in winter and high salinity reduced the biological removal efficiency for $\mathrm{NH}_{4}{ }^{+}-\mathrm{N}$. Therefore, screening highefficiency degradation bacteria is a necessary method, and a previous study confirmed that an effective conversion process for $\mathrm{NH}_{4}{ }^{+}-\mathrm{N}$ could be achieved by salt- and cold-tolerant AOB under high-salt and low-temperature condition (Huang et al., 2017). Nevertheless, the application of high-effectivity degrading strains in a large-scale watershed faces an inevitable problem, i.e., the dilution of tide for using highly efficient $\mathrm{AOB}$, which results in more difficult and inefficient application of traditional adsorption materials and biotechnology.

The immobilization technology of high-efficiency degradation bacteria is to fix the bacteria on a carrier, so as to solve the problem that the free high-efficiency degradation bacteria are washed away in the dynamic river. Hence, this technology is a potential application for wetland environmental restoration. Some previous studies have shown that immobilized strains could effectively remove reactive dyes, mineralize $\mathrm{Ca}^{2+}$ and $\mathrm{Mg}^{2+}$, and remove manganese (Reddy and Osborne, 2020; Yan et al., 2020; Atcharaporn et al., 2020). Meanwhile, whether this technology can maintain the degradation performance for salt- and coldtolerant $\mathrm{AOB}$ converting $\mathrm{NH}_{4}{ }^{+}-\mathrm{N}$ and resist low temperature and high salt environment is worth discussing.

Therefore, the purpose of this study is to propose a method that can be applied to remove $\mathrm{NH}_{4}{ }^{+}-\mathrm{N}$ in LEW. Based on the previous research, BCCP was prepared and the influence of calcined temperature and program on its adsorption performance was discussed. Then, immobilized $\mathrm{AOB}$ was explored to investigate the contribution of different immobilization methods on $\mathrm{NH}_{4}{ }^{+}-\mathrm{N}$ degradation. Finally, salt- and cold-resistance characteristics of immobilization were further studied to deepen the application value of immobilization technology.

\section{MATERIALS AND METHODS}

\section{Biochar, Clay, and Ammonia-Oxidizing Bacteria}

The reed straw selected was washed with deionized water and dried at $105^{\circ} \mathrm{C}$ for $24 \mathrm{~h}$ in an open crucible to remove the surface magazine. Then it was crushed with a micro plant crusher (Beijing Weiye, Z102), screened to obtain $0.85 \mathrm{~mm}$ reed powder, and placed in a quartz tube inside a tube furnace to produce the biochar through slow pyrolysis in a $\mathrm{N}_{2}$ environment at $600^{\circ} \mathrm{C}$ for $3 \mathrm{~h}$, respectively. The biochar samples were washed with deionized water several times to remove impurities, and then grinded into $0.15 \mathrm{~mm}$ powder and sealed in a container for further testing. The detailed information of the biochar characteristics is shown in Huang et al. (2020), and the composition of $\mathrm{C}, \mathrm{H}, \mathrm{O}$, and $\mathrm{N}$ were $72.5,4.18,18.32$, and $0.67 \%$, respectively. The proportion of ash was $12.31 \%$.

The clay was placed in an open crucible at $105^{\circ} \mathrm{C}$ for $24 \mathrm{~h}$. Then it was crushed with a micro plant crusher (Beijing Weiye, Z102) and screened to obtain $0.15 \mathrm{~mm}$ clay powder.

The AOB was isolated from LEW with the characteristics of cold and salt tolerance and similar to the branch Ochrobactrum sp. The obtained $16 \mathrm{~S}$ rDNA sequence of HXN-1 strain was registered in GenBank under accession numbers KP276672, and the characteristics of Ochrobactrum sp. and phylogenetic tree are listed in Huang et al. (2017). The details were as follows: catalase test $(-)$, starch hydrolyzing enzyme test $(+)$, citrate utilization test $(+)$, MR test $(-)$, glucose fermentation test $(-)$, VP test $(-)$, and indole test $(-)$. The $\mathrm{NH}_{4}{ }^{+}-\mathrm{N}$ removal rate by Ochrobactrum sp. exceeds $60 \%$ at $15^{\circ} \mathrm{C}$ and $20 \%$ condition.

\section{Preparation of Biochar/Clay Composite Particle}

The optimum preparation formulation of BCCP and the proportion of raw material obtained in a previous study are demonstrated as follows: $15 \%$ biochar, $79 \%$ clay, $3 \% \mathrm{Na}_{2} \mathrm{SiO}_{3}$, and $3 \% \mathrm{NaHCO}_{3}$ (v/v) (Huang et al., 2020). These materials were mixed, placed in a disc-type ball-making machine (BY-300; TianZhuo, Zhengzhou) to produce BCCP with a particle size of $8 \sim 10 \mathrm{~mm}$, and dried at $45^{\circ} \mathrm{C}$ for $6 \mathrm{~h}$ in a constant temperature drying oven. The calcined process was slow pyrolysis in a $\mathrm{N}_{2}$ environment at $400,450,500,550,600$, and $700^{\circ} \mathrm{C}$ for $3 \mathrm{~h}$, respectively. Besides, the heating rate and holding time were optimized and their optimization scope was $5 \sim 20{ }^{\circ} \mathrm{C} \mathrm{min}-1$ and $1 \sim 4$ h, respectively. The firing process is shown in Figure 1. The calcined process orthogonal test level of BCCP is demonstrated in Table 1.

\section{Adsorption Experiment of Biochar/Clay Composite Particles for Ammonia Nitrogen \\ Adsorption Batch Experiment}

BCCP (1.0 g) calcined with six different temperatures were put into a $50-\mathrm{ml}$ flask with pure $\mathrm{NH}_{4}{ }^{+}-\mathrm{N}$ solution and shaken at $150 \mathrm{r} \mathrm{min}{ }^{-1}$ for $300 \mathrm{~min}$ at $25^{\circ} \mathrm{C}$. Samples were collected at $5,10,20,40,60,90,120,150,180,240$, and $300 \mathrm{~min}$. The samples were filtrated by $0.45-\mu \mathrm{m}$ RC membrane to determine $\mathrm{NH}_{4}{ }^{+}-\mathrm{N}$ concentration.

The adsorption capacity during the adsorption period was calculated by Equation (1):

$$
q_{t}=\left(C_{0}-C_{t}\right) \frac{\mathrm{V}}{\mathrm{m}}
$$

where $q_{t}$ is the amount of $\mathrm{NH}_{4}^{+}-\mathrm{N}$ during the adsorption time $\left(\mathrm{mg} \mathrm{kg}^{-1}\right) ; C_{0}$ and $C_{t}\left(\mathrm{mg} \mathrm{L}^{-1}\right)$ are the initial $\mathrm{NH}_{4}{ }^{+}$ $\mathrm{N}$ concentrations and different time residual concentration, 


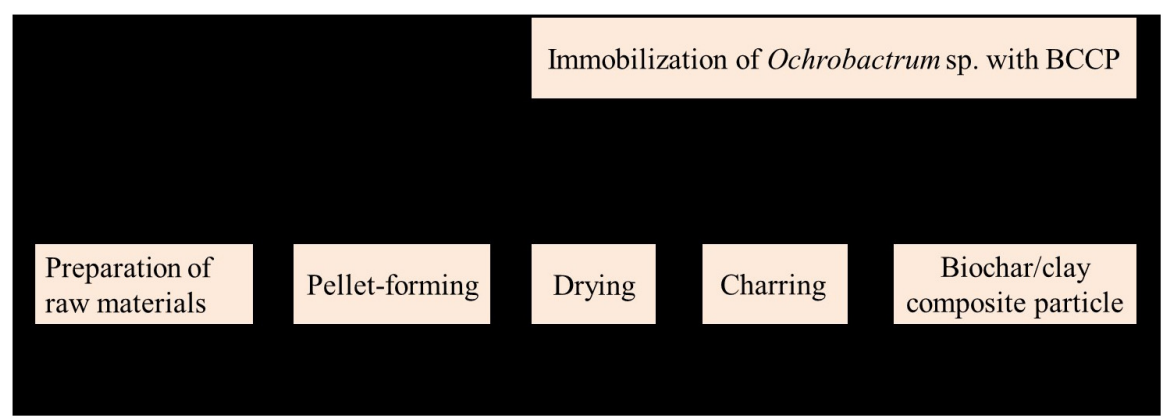

FIGURE 1 | Calcined program of BCCP and immobilization of Ochrobactrum sp.

respectively. $\mathrm{V}$ is the volume of reaction system $(\mathrm{L})$, and $\mathrm{m}$ is the mass of adsorbent (g).

\section{Adsorption Kinetics}

The data coming from adsorption batch experiment were fitted with pseudo-first- and pseudo-second-order models and intraparticle model, the expressions as following Equations (2)-(4):

$$
\begin{array}{rlrl}
\mathrm{q}_{\mathrm{t}} & =\mathrm{q}_{\mathrm{e}}\left(1-\mathrm{e}^{-\mathrm{K}_{1} \mathrm{t}}\right) & & (\text { Firstorder }) \\
\frac{\mathrm{t}}{\mathrm{q}_{\mathrm{t}}}=\frac{1}{\mathrm{~K}_{2} \mathrm{q}_{\mathrm{e}}^{2}}+\frac{\mathrm{t}}{\mathrm{q}_{\mathrm{e}}} & & \text { (Secondorder) } \\
\mathrm{q}_{\mathrm{t}} & =\mathrm{K}_{\mathrm{p}} \sqrt{\mathrm{t}}+\mathrm{C} & & \text { (Intraparticlemodel) }
\end{array}
$$

where $\mathrm{q}_{\mathrm{e}}\left(\mathrm{mg} \cdot \mathrm{g}^{-1}\right)$ is the adsorbed amounts of $\mathrm{NH}_{4}{ }^{+}-\mathrm{N}$ by the BCCP at equilibrium time, and $\mathrm{q}_{\mathrm{t}}$ is the adsorbed amount at a given time interval ( $t$ ). $K_{1}$ and $K_{2}$ are the rate constants for the pseudo-first- and pseudo-second-order models, respectively. Kp

\begin{tabular}{|c|c|c|c|c|}
\hline Levels & $\begin{array}{c}\text { Calcined } \\
\text { temperature }\left({ }^{\circ} \mathrm{C}\right)\end{array}$ & $\begin{array}{l}\text { Heating rate } \\
\left({ }^{\circ} \mathrm{C} \mathrm{min}^{-1}\right)\end{array}$ & $\begin{array}{l}\text { Holding } \\
\text { time (h) }\end{array}$ & $\begin{array}{l}\text { Empty } \\
\text { column }\end{array}$ \\
\hline 1 & 400 & 5 & 1 & 1 \\
\hline 2 & 400 & 10 & 2 & 2 \\
\hline 3 & 400 & 15 & 3 & 3 \\
\hline 4 & 400 & 20 & 4 & 4 \\
\hline 5 & 500 & 5 & 2 & 3 \\
\hline 7 & 500 & 10 & 1 & 4 \\
\hline 7 & 500 & 15 & 4 & 1 \\
\hline 8 & 600 & 20 & 3 & 2 \\
\hline 9 & 600 & 5 & 3 & 4 \\
\hline 10 & 600 & 10 & 4 & 3 \\
\hline 11 & 600 & 15 & 1 & 2 \\
\hline 12 & 600 & 20 & 2 & 1 \\
\hline 13 & 700 & 5 & 4 & 2 \\
\hline 14 & 700 & 10 & 3 & 1 \\
\hline 15 & 700 & 15 & 2 & 4 \\
\hline 16 & 700 & 20 & 1 & 3 \\
\hline
\end{tabular}
is the intraparticle diffusion rate constant $\left(\mathrm{mg} \cdot \mathrm{g}^{-1} \mathrm{~min}^{1 / 2}\right)$, and

TABLE 1 | Calcined process orthogonal test level of BCCP.
$\mathrm{C}\left(\mathrm{mg} \mathrm{g}^{-1}\right)$ is a constant that reflects the boundary layer effect. A plot of $\mathrm{q}_{\mathrm{t}}$ against $\mathrm{t}^{1 / 2}$ gave a linear relationship from which the $\mathrm{Kp}$ value was determined from the slope and $\mathrm{C}$ as the intercept.

\section{Adsorption Isotherms}

Freundlich and Langmuir equations were used to fit the adsorption isotherms of BCCP with different calcined temperatures, and the equation is given by

$$
\begin{aligned}
& \log q_{e}=\log K_{F}+\frac{1}{n} \log C_{e} \quad \text { (Freundlichequation) } \\
& q_{\mathrm{e}}=\frac{q_{\max } K_{\mathrm{L}} C_{\mathrm{e}}}{1+K_{\mathrm{L}} C_{\mathrm{e}}} \quad \text { (Langmuirequation) }
\end{aligned}
$$

where $q_{e}\left(\mathrm{mg} \cdot \mathrm{g}^{-1}\right)$ is the amount of $\mathrm{NH}_{4}{ }^{+}-\mathrm{N}$ adsorbed by the BCCP at equilibrium time, and $q_{\max }\left(\mathrm{mg} \mathrm{g}^{-1}\right)$ and $K_{L}\left(\mathrm{~L} \mathrm{mg}^{-1}\right)$ are Langmuir constants that indicate the maximum adsorption and relative binding energy of BCCP, respectively. $K_{F}$ and $n$ are Freundlich constants that measure the relative $\mathrm{NH}_{4}{ }^{+}-\mathrm{N}$ adsorption capacity and adsorption intensity of BCCP, respectively, while $C_{e}\left(\mathrm{mg} \mathrm{L}^{-1}\right)$ denotes the equilibrium concentration of $\mathrm{NH}_{4}{ }^{+}-\mathrm{N}$ remaining in solution after adsorption is complete.

\section{Immobilization of Ochrobactrum sp. With Biochar/Clay Composite Particle}

The AOB strain HXN-1 (Ochrobactrum sp.) used in this study was enriched with culture medium to $\mathrm{OD}_{600}=0.6$. The prepared BCCPs were soaked into high-efficiency degrading bacteria $\left(\mathrm{OD}_{600}\right)$ for $24 \mathrm{~h}$ and afterward were transferred into the embedding solution for immobilization.

Two immobilization groups were set with sodium alginate (SA) and polyvinyl alcohol (PVA). (1) SA immobilization group: $2 \%$ SA aqueous solution and $2 \% \mathrm{CaCl}_{2}$ aqueous solution were mixed and autoclaved at $121^{\circ} \mathrm{C}$ for $30 \mathrm{~min}$. (2) SA/PVA immobilization group: 2\% SA and 12\% PVA aqueous solutions were prepared according to the aforementioned method. For the BCCP adhesive, two kinds of embedding liquid were transferred into $2 \% \mathrm{CaCl}_{2}$ solution and saturated boric acid$2 \% \mathrm{CaCl}_{2}$ solution, respectively, and afterward placed in a $4^{\circ} \mathrm{C}$ refrigerator for $24 \mathrm{~h}$. 


\section{Batch Experiment of Ammonia Nitrogen Degradation by Ochrobactrum sp.} Influence of Immobilization Material and Bacteria on Ammonia Nitrogen Degradation

HXN-1was made into gel particles by the method of 2.4 and named SA-B and SA/PVA-B and the blank gel particles were named SA-C and SA/PVA-C. SA and PVA as base material to immobilize Ochrobactrum sp. was named SA/PVA-B, and as control group without adding Ochrobactrum sp. was named SA/PVA-C. The aforementioned gel particles were put into $100 \mathrm{ml}$ of $50 \mathrm{mg} \mathrm{L}^{-1} \mathrm{NH}_{4}{ }^{+}-\mathrm{N}$ medium, placed in a shaking incubator at $25^{\circ} \mathrm{C}, 180 \mathrm{r} \mathrm{min}^{-1}$ for 7 days, and $\mathrm{NH}_{4}{ }^{+}-\mathrm{N}$ concentration was measured daily. The medium characteristics were demonstrated in Huang et al. (2017). Free bacteria (FB) were used as a control group.

\section{Influence of Salinity and Temperature on Ammonia Nitrogen Degradation}

Six kinds of gel particles were, respectively, put into $100 \mathrm{ml}$ of $50 \mathrm{mg} \mathrm{L}{ }^{-1} \mathrm{NH}_{4}{ }^{+}-\mathrm{N}$ solution with different salinities $(0,5,15$, 25 , and $35 \% 0$ ) under $25^{\circ} \mathrm{C}$ condition. Also, the same six kinds of gel particles were with different temperatures $(15,20,25,30$, and $35^{\circ} \mathrm{C}$ ) with $5 \%$ salinity. All of these were placed in a shaking incubator and shocked with $180 \mathrm{r} \mathrm{min}^{-1}$ for 10 days and $\mathrm{NH}_{4}{ }^{+}$$\mathrm{N}$ concentration was measured daily. Free bacteria were used as a control group.

\section{Analytical Method}

Fourier-transform infrared spectroscopy (FTIR) spectra were recorded between 400 and $4000 \mathrm{~cm}^{-1}$ on a Nicolet 6,700 Fourier transform spectrometer. Clay, biochar, and BCCP were pelletized from a mixture of $1.5 \mathrm{mg}$ dried sample with $200 \mathrm{mg} \mathrm{KBr}$.

The water sample was filtered with a $0.45-\mu \mathrm{m}$ filter membrane (Minisart RC 15), and the $\mathrm{NH}_{4}{ }^{+}-\mathrm{N}$ concentration was measured with a Nessler reagent. Each sample was measured in triplicate, and their average value was analyzed.

\section{Statistical Analysis}

All experiment groups were set in three replicates, and the average values of each sample were calculated and showed in charts. Origin 8.6 software was used for drawing figures.

\section{RESULTS AND DISCUSSION}

\section{Effect of Calcined Program on Ammonia Nitrogen Adsorption by Biochar/Clay Composite Particle}

To a certain extent, the control of calcined program (calcined temperature, heating rate, holding time) changes the surface structure of BCCP and then affects the adsorption performance for $\mathrm{NH}_{4}{ }^{+}-\mathrm{N}$. Previous studies have shown that the adsorption performance of biochar was affected by calcined temperature and heating rate (Yakkala et al., 2013; Mahdi et al., 2018). Therefore, orthogonal experiment was used in this study to discuss the effect of calcined program on $\mathrm{NH}_{4}{ }^{+}-\mathrm{N}$ adsorption by BCCP, and the results are demonstrated in Table 2. Different BCCPs prepared by calcined temperature, holding time, and heating rate resulted in unequal $\mathrm{NH}_{4}{ }^{+}-\mathrm{N}$ adsorption capacity. The minimum adsorption capacity was $0.394 \mathrm{mg} \mathrm{g}^{-1}$, the maximum value was $0.454 \mathrm{mg}$ $\mathrm{g}^{-1}$, and the average adsorption capacity was $0.424 \mathrm{mg} \mathrm{g}^{-1}$. The adsorption capacity of BCCP fluctuated with the increase of calcined temperature, and the best adsorption capacity appeared at $400^{\circ} \mathrm{C}$; the adsorption capacity was $0.446 \mathrm{mg} \mathrm{g}^{-1}$, and the lowest was $500^{\circ} \mathrm{C}$ with the adsorption capacity reducing to $0.402 \mathrm{mg} \mathrm{g}^{-1}$.

Heating rate has a significant impact on the adsorption properties of BCCP and the adsorption capacity of BCCP decreased first and then increased with the increase of heating rate. The maximum adsorption capacity appeared at $20^{\circ} \mathrm{C} \mathrm{min}^{-1}$. It can be interpreted that the increase of flexural strength decreased the loss tangent $\tan \alpha$ when the temperature rose slowly. Meanwhile, the material was uniform with low porosity. However, too fast temperature rising would make it difficult to discharge the gas in BCCP and inhibited the reduction of porosity. Therefore, the adsorption capacity increased when the heating rate was from 10 to $20^{\circ} \mathrm{C} \mathrm{min}^{-1}$.

The increase of holding time also promoted the adsorption capacity of BCCP first and then decreased. The maximum value appeared at $2 \mathrm{~h}$ with $0.437 \mathrm{mg} \mathrm{g}^{-1}$ adsorption capacity. The influence of holding time on adsorption properties of BCCPs mainly included two aspects, i.e., one was to stabilize the physical and chemical changes of materials, and the other was

TABLE $2 \mid \mathrm{NH}_{4}{ }^{+}-\mathrm{N}$ adsorption by BCCP with different calcined programs.

\begin{tabular}{|c|c|c|c|c|c|}
\hline Levels & $\begin{array}{c}\text { Calcined } \\
\text { temperature } \\
\left({ }^{\circ} \mathrm{C}\right)\end{array}$ & $\begin{array}{l}\text { Heating rate } \\
\left({ }^{\circ} \mathrm{C} \mathrm{min}^{-1}\right)\end{array}$ & $\begin{array}{l}\text { Holding } \\
\text { time (h) }\end{array}$ & $\begin{array}{l}\text { Empty } \\
\text { column }\end{array}$ & $\begin{array}{c}\text { Result } \\
\left(\mathrm{mg} \mathrm{g}^{-1}\right)\end{array}$ \\
\hline 1 & 400 & 5 & 1 & 1 & 0.454 \\
\hline 2 & 400 & 10 & 2 & 2 & 0.451 \\
\hline 3 & 400 & 15 & 3 & 3 & 0.444 \\
\hline 4 & 400 & 20 & 4 & 4 & 0.435 \\
\hline 5 & 500 & 5 & 2 & 3 & 0.412 \\
\hline 7 & 500 & 10 & 1 & 4 & 0.397 \\
\hline 7 & 500 & 15 & 4 & 1 & 0.401 \\
\hline 8 & 500 & 20 & 3 & 2 & 0.396 \\
\hline 9 & 600 & 5 & 3 & 4 & 0.421 \\
\hline 10 & 600 & 10 & 4 & 3 & 0.415 \\
\hline 11 & 600 & 15 & 1 & 2 & 0.409 \\
\hline 12 & 600 & 20 & 2 & 1 & 0.492 \\
\hline 13 & 700 & 5 & 4 & 2 & 0.415 \\
\hline 14 & 700 & 10 & 3 & 1 & 0.418 \\
\hline 15 & 700 & 15 & 2 & 4 & 0.394 \\
\hline 16 & 700 & 20 & 1 & 3 & 0.426 \\
\hline Average value 1 & 0.446 & 0.426 & 0.421 & 0.441 & 0.424 \\
\hline Average value 2 & 0.402 & 0.420 & 0.437 & 0.418 & \\
\hline Average value 3 & 0.434 & 0.421 & 0.420 & 0.424 & \\
\hline Average value 4 & 0.413 & 0.437 & 0.417 & 0.412 & \\
\hline Range analysis & 0.044 & 0.017 & 0.020 & 0.029 & \\
\hline Primary relation & & ACB & & & \\
\hline
\end{tabular}

Optimal scheme $\quad \mathrm{A} 1 \mathrm{~B} 4 \mathrm{C} 2$ (calcined temperature: $400^{\circ} \mathrm{C}$, heating rate: $20^{\circ} \mathrm{C} \mathrm{m^{-1 }}$, holding time: $2 \mathrm{~h}$ ) 
to homogenize the tissue structure. Too long holding time was not conducive to the formation of a strong skeleton, reduced mechanical properties, and caused glaze crack (Yang and Chow, 2019). Therefore, the holding time needed to be moderate, and the best holding time was $2 \mathrm{~h}$ in this study.

The primary relation of calcined temperature, heating rate, and holding time on $\mathrm{NH}_{4}{ }^{+}-\mathrm{N}$ adsorption was judged according to the magnitude of extreme difference; the primary and secondary sequences of the three ingredients were ACB, which proved that calcined temperature occupied the most prominent position, and then holding time and heating rate owned the least impact. Besides, it was concluded that A1B4C2 was the best preparation condition for BCCP, and the parameters were as follows: calcined temperature $400^{\circ} \mathrm{C}$, heating rate $20^{\circ} \mathrm{C} / \mathrm{min}$, and holding time $2 \mathrm{~h}$.

\section{Effect of Calcined Temperature on Ammonia Nitrogen Adsorption by Biochar/Clay Composite Particle}

\section{Ammonia Nitrogen Removal Performance}

$\mathrm{NH}_{4}{ }^{+}-\mathrm{N}$ adsorption performances from aqueous solution by six BCCPs with different temperatures were conducted, and the results are shown in Figure 2. The adsorption equilibrium time among six experimental groups was $180 \mathrm{~min}$, and the $\mathrm{NH}_{4}{ }^{+}-\mathrm{N}$ removal efficiency by BCCP adsorption was about $29.4 \sim 34.5 \%$. The removal efficiency at $400^{\circ} \mathrm{C}$ group was better than that of the other four groups with the adsorption capacity of $0.473 \mathrm{mg}$ $\mathrm{g}^{-1}$. However, the value decreased first and then increased with the increase of calcined temperature. The same phenomenon existed in the research of Chen et al. (2018) who found that the surface area and pore volume of bentonite increased to 56.09 and $0.0611 \mathrm{~cm}^{3} \mathrm{~g}^{-1}$ when the calcined temperature was $400^{\circ} \mathrm{C}$, respectively, but sharply declined to 30.53 and $0.051 \mathrm{~cm}^{3} \mathrm{~g}^{-1}$ at $800^{\circ} \mathrm{C}$. Yan et al. (2018) prepared a kind of porous diatomite microsphere by spray drying method and the methylene blue adsorption capacity and removal efficiency demonstrated the maximum values when the calcined temperature was $600^{\circ} \mathrm{C}$, and

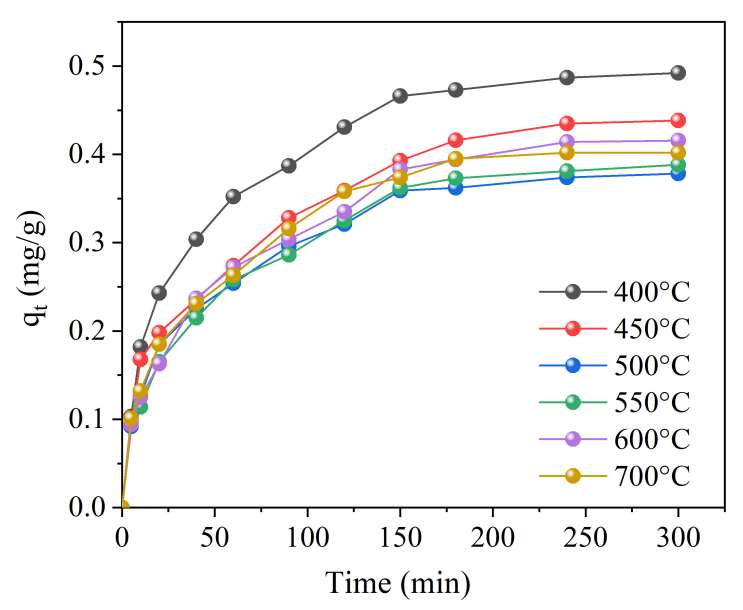

FIGURE 2 | Adsorption capacity at different calcined temperatures. decreased when the temperature rose. Ojeda-López et al. (2021) found that adsorbent/adsorbate interactions for $\mathrm{CO}_{2}, \mathrm{CH}_{4}$, and $\mathrm{N}_{2}$ were inversely proportional to calcined temperature (CMF$600>$ CMF-700 > CMF-800) by the mean of the isosteric enthalpy of adsorption measurements.

This was because the pore volume and Brunauer-EmmettTeller (BET) surface area reached maximum at some temperature and decreased further with the increase of calcined temperature (Kar and Equeenuddin, 2019). The organic compounds presenting in biochar or clay would condense on the surface of the particles, and clog the pores to decrease specific surface area after cooling with the increase of calcined temperature (Atkinson et al., 2010). Also, four forms of water existed in clay minerals (i.e., surface adsorbed water, pore adsorbed water, crystalline water combined with octahedral cations at the edge of pore, and cationic structural water combined with octahedral layer), and high temperature led to the adsorbed water, pore water, and bound water in the material lost when the temperature was less than $600^{\circ} \mathrm{C}$, and the carbon in biochar and clay was oxidized. Meanwhile, the decomposition of $\mathrm{NaHCO}_{3}$ increased the pores and adsorption in the green body. The decrease of adsorption capacity from $500^{\circ} \mathrm{C}$ might be due to the fission of $\mathrm{C} 400$ biochar fired at $400^{\circ} \mathrm{C}$ with the temperature rising to $500^{\circ} \mathrm{C}$, and the forming of ash adsorbed in the pores of BCCP and reduced its adsorption performance for $\mathrm{NH}_{4}{ }^{+}-\mathrm{N}$. When the temperature exceeded $600^{\circ} \mathrm{C}$, the water in BCCP evaporated and decomposed violently, and the pore structure was deformed, the porosity decreased, and the adsorption capacity decreased.

Many materials were reported to adsorb $\mathrm{NH}_{4}{ }^{+}-\mathrm{N}$, such as slag, biochar, and coal slag balls. The $\mathrm{NH}_{4}{ }^{+}-\mathrm{N}$ adsorption behavior of slag was found in either neutral or alkaline conditions with $3.1 \mathrm{mg} \mathrm{g}^{-1}$ sorption capacity (Zhang et al., 2013). Vu et al. (2017) prepared biochar using corncob and the highest adsorption capacity was $22.6 \mathrm{mg} \mathrm{g}^{-1}$. However, Kong et al. (2021) reported that the biochar prepared from distilled spirit achieved lees adsorption capacity (5.92 $\mathrm{mg} \mathrm{g}^{-1}$ ). Wang et al. (2016) prepared coal slag balls using modified coal slag and organic binder (PVA) and the $\mathrm{NH}_{4}{ }^{+}-\mathrm{N}$ adsorption capacity was only $0.09 \mathrm{mg} \mathrm{g}^{-1}$. The higher adsorption capacity of biochar depends on the large specific surface area and abundant adsorption sites (Li et al., 2018, 2019), and composition was also a key factor affecting the adsorption capacity. In this study, the high proportion of inorganic clay in BCCP resulted in small adsorption capacity.

\section{Adsorption Kinetics and Isotherm}

Adsorption kinetics could be fitted by first-order kinetic model, second-order kinetic model, and intraparticle model, and all of them could well fit the $\mathrm{NH}_{4}{ }^{+}-\mathrm{N}$ adsorption process by BCCPs with different calcined temperature (Table 3). Comparing with first-order kinetic and intraparticle diffusion models, the secondorder kinetic model was more suitable for describing the $\mathrm{NH}_{4}{ }^{+}$$\mathrm{N}$ adsorption process by BCCPs, which was reflected by chemical adsorption processes including ion exchange among chemical bonds and adsorption process. $\mathrm{Si}-\mathrm{O}-\mathrm{Si},-\mathrm{OH}$ functional group on BCCP was involved in the reaction between chemical bonds during $\mathrm{NH}_{4}{ }^{+}-\mathrm{N}$ adsorption process (Figure 3). Yan et al. (2018) 
TABLE 3 | The adsorption kinetic parameters of BCCP under different calcined temperatures.

\begin{tabular}{|c|c|c|c|c|c|c|c|c|c|}
\hline \multirow[b]{2}{*}{$\mathbf{T}$} & \multirow[b]{2}{*}{$q_{e}$} & \multicolumn{3}{|c|}{ Pseudo-first-order } & \multicolumn{3}{|c|}{ Pseudo-second-order } & \multicolumn{2}{|c|}{ Intraparticle diffusion } \\
\hline & & $\mathrm{K}_{1}$ & qeq & $R^{2}$ & $\mathrm{~K}_{2}$ & $\mathrm{q}_{\mathrm{eq}}$ & $R^{2}$ & $\mathbf{k}_{\mathrm{p}}$ & $R^{2}$ \\
\hline$\left({ }^{\circ} \mathrm{C}\right)$ & $\left(\mathrm{mg} \mathrm{g}^{-1}\right)$ & $\left(\min ^{-1}\right)$ & $\left(\mathbf{m g ~ g}{ }^{-1}\right)$ & & {$\left[g(\mathrm{mg} \mathrm{min})^{-1}\right]$} & $\left(\mathrm{mg} \mathrm{g}^{-1}\right)$ & & {$\left[\mathrm{g}\left(\mathrm{mg} \mathrm{min} \mathrm{m}^{0.5}\right)^{-1}\right]$} & \\
\hline 400 & 0.492 & 0.031 & 0.462 & 0.925 & 0.077 & 0.525 & 0.980 & 0.025 & 0.900 \\
\hline 450 & 0.438 & 0.024 & 0.409 & 0.871 & 0.070 & 0.468 & 0.940 & 0.023 & 0.949 \\
\hline 500 & 0.378 & 0.028 & 0.356 & 0.908 & 0.092 & 0.405 & 0.968 & 0.019 & 0.923 \\
\hline 550 & 0.388 & 0.023 & 0.369 & 0.923 & 0.069 & 0.428 & 0.967 & 0.021 & 0.939 \\
\hline 600 & 0.416 & 0.022 & 0.395 & 0.926 & 0.061 & 0.460 & 0.970 & 0.023 & 0.946 \\
\hline 700 & 0.402 & 0.025 & 0.386 & 0.914 & 0.075 & 0.442 & 0.964 & 0.021 & 0.926 \\
\hline
\end{tabular}

used porous diatomite microsphere to adsorb methylene blue and also found that the adsorption process followed the pseudosecond-order kinetic model.

The adsorption equilibrium isotherm could reflect the distribution of adsorbate molecules in liquid and solid phases under an equilibrium state (Huang et al., 2020). Both Langmuir isotherm and Freundlich isotherm models could better fit $\mathrm{NH}_{4}{ }^{+}$$\mathrm{N}$ adsorption by BCCP prepared with different temperatures (Table 4). However, Freundlich model with $R^{2}=0.941 \sim 0.988$ was more suitable than Langmuir model $\left(R^{2}=0.880 \sim 0.946\right)$, and the conclusion was coincident with Yan et al. (2018). Adsorption site energy distribution characteristic and curvature in the isotherm could be responded by $n$ in Freundlich model (Huang et al., 2020). The value of $n$ was between 1 and 10 in this study, which proved that all adsorption processes of BCCPs with different calcined temperatures were preferential adsorption.

\section{Fourier-Transform Infrared Spectroscopy Spectra of Biochar/Clay Composite Particles Under Different Temperatures}

The FTIR is an essential technique to qualitatively determine characteristic functional groups of the adsorbents (Figure 3).

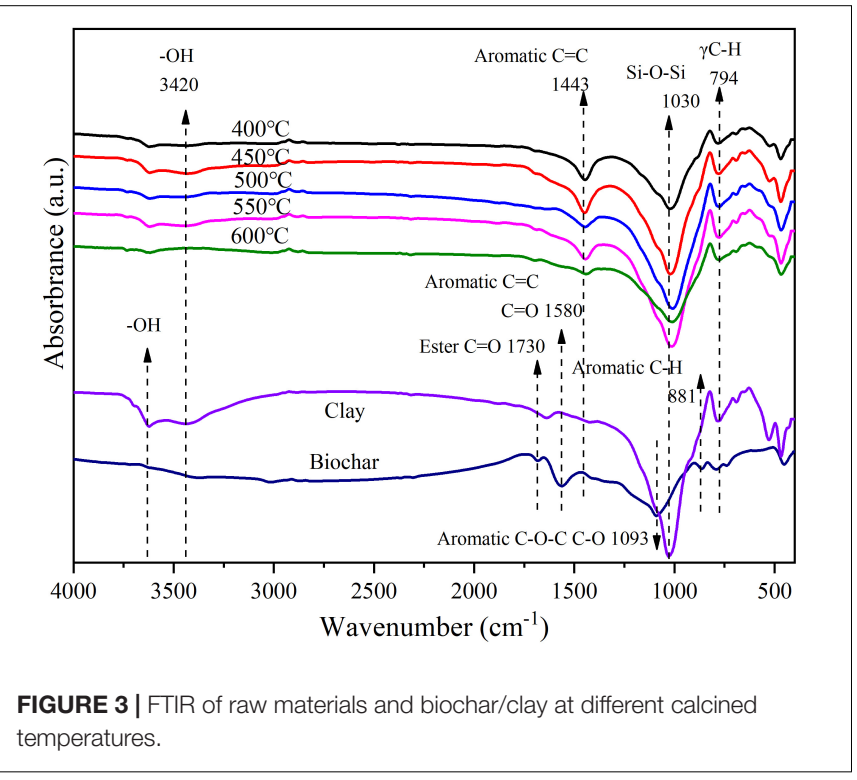

The peak of IR curved at $1,030 \mathrm{~cm}^{-1}$ exhibited the introducing of Si-O-Si bonds on the BCCPs (Liu et al., 2012). The bands appearing below $1,100 \mathrm{~cm}^{-1}$ might be attributed to $\mathrm{Si}-$ $\mathrm{O}$ stretching, Si-O-Si bending, Si-O-Al bending, and Si-OMg bending vibrations (Chen et al., 2017). For the otherwise typical bands, the intensity of the $\mathrm{OH}$ stretch at approximately $3,420 \mathrm{~cm}^{-1}$ in the spectrum of clay was considerably larger than in the FTIR spectrum of the BCCP. The intensity of the $\mathrm{CO}_{3}{ }^{2-}$ stretch at approximately $1,440 \mathrm{~cm}^{-1}$ in the spectrum of BCCPs appeared depending on the addition of $\mathrm{NaHCO}_{3}$.

\section{Ammonia Nitrogen Degradation Performance by Immobilizing Ochrobactrum sp. on Biochar/Clay Composite Particle} Comparison of Immobilization Methods for Ammonia Nitrogen Degradation

BCCP, as a carrier for microbial immobilization, is an effective method to ensure that the efficient flora continue its degradation efficiency in natural water and avoid the risk of free bacteria being dispersed to reduce its pollutant degradation performance (Huang et al., 2020). For maintaining its degradation efficiency, immobilization method becomes the main control factor restricting pollutant transformation in microbial immobilization process. In this study, immobilization method was studied first and the results are shown in Figure 4A. The immobilization

TABLE 4 | The Langmuir and Freundlich adsorption isotherm constant of BCCP under different calcined temperatures.

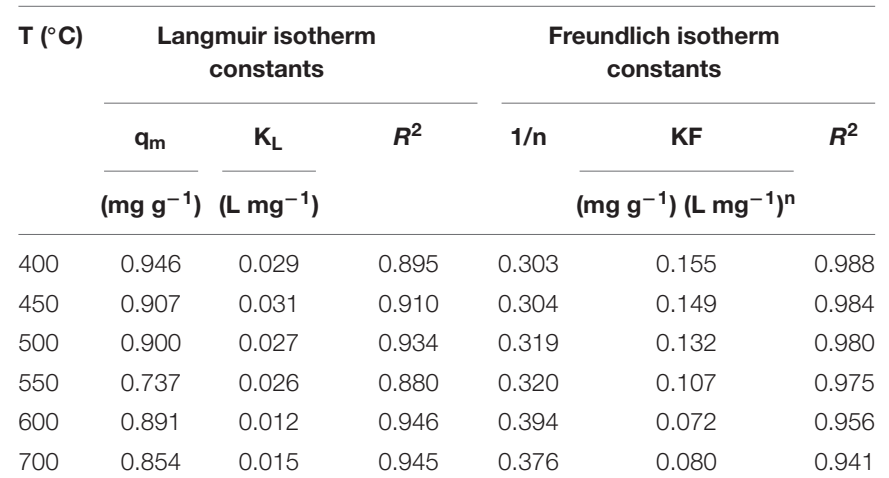



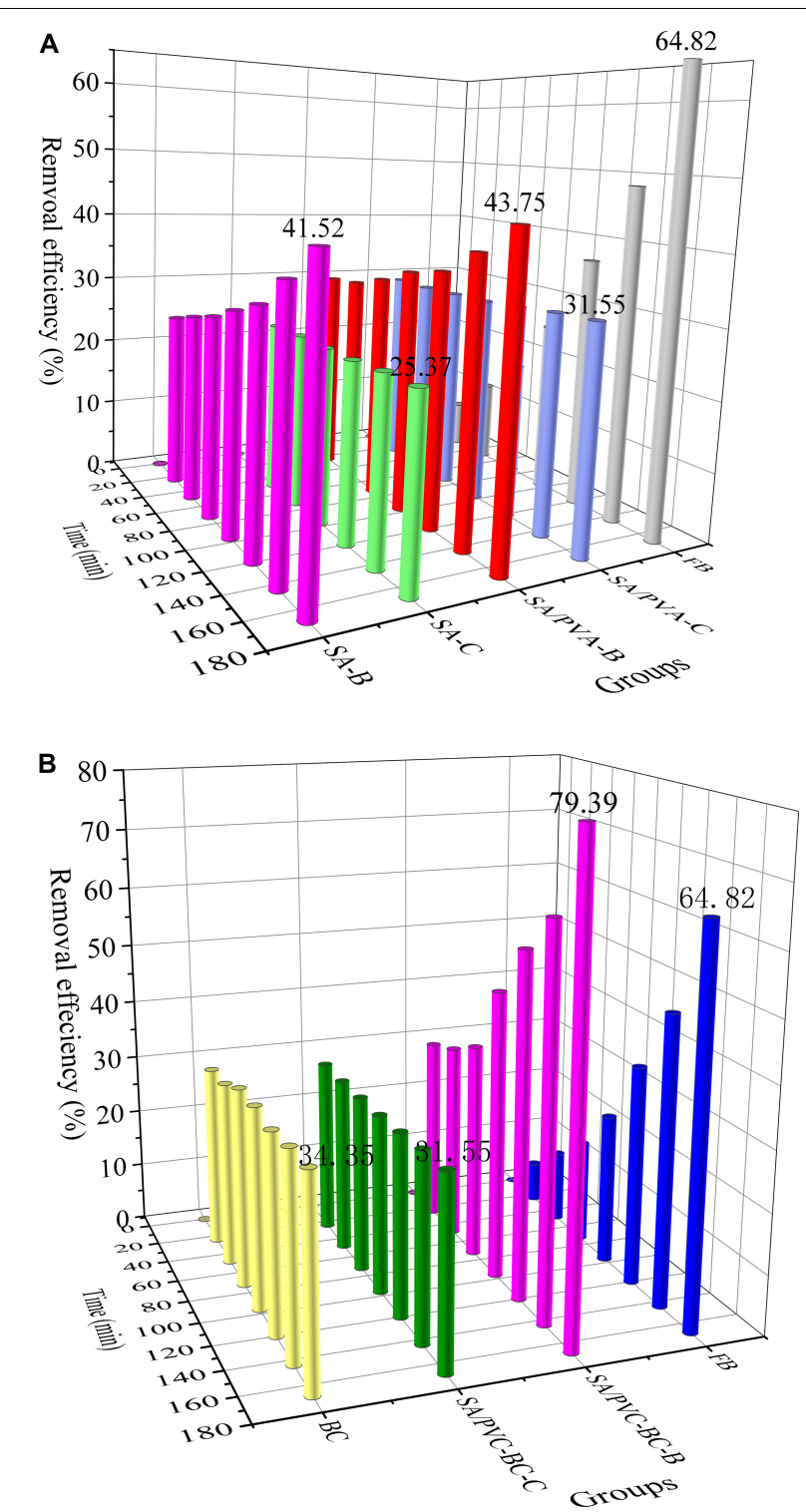

FIGURE 4 | $\mathrm{NH}_{4}{ }^{+}-\mathrm{N}$ removal efficiency by immobilized Ochrobactrum sp. (A) Comparison of immobilization methods and (B) $\mathrm{NH}_{4}{ }^{+}-\mathrm{N}$ removal efficiency by immobilization of Ochrobactrum sp. on BCCP. FB, free Ochrobactrum sp. without any immobilization methods; SA-B, SA as base material to immobilize Ochrobactrum sp.; SA-C, SA as control group without adding Ochrobactrum sp.; SA/PVA-B, SA and PVA as base material to immobilize Ochrobactrum sp.; SA/PVA-C, SA and PVA as control group without adding Ochrobactrum sp.; BC, BCCP alone for adsorption as control group.

of Ochrobactrum sp. exhibited preferable nitrogen removal capacities when ammonium chloride was used as the sole nitrogen source. During the initial stage of the experiment (the first $24 \mathrm{~h}$ ), the gel particles (SA-C and SA/PVA-C groups) adsorbed $\mathrm{NH}_{4}{ }^{+}-\mathrm{N}$ from solution with high efficiency and their adsorption efficiencies were 22.59 and 29.59\%, respectively, which were $10 \sim 19 \%$ higher than that of the conclusion of Yan et al. (2020). Compared with two immobilization methods, on the contrary, the biodegradation performance of free Ochrobactrum sp. (FB group) at initial stage was very low (only $6.87 \% \mathrm{NH}_{4}{ }^{+}$. $\mathrm{N}$ was transformed in $24 \mathrm{~h}$ ) and $\mathrm{NH}_{4}{ }^{+}-\mathrm{N}$ removal efficiency reached $64.82 \%$ after $168 \mathrm{~h}$. However, the value was 41.52 and $43.75 \%$ in SA-B and SA/PVA-B group, respectively, and they did not beat the FB group. Although the removal efficiency decreased, it could also be concluded that SA/PVA as immobilized material was more appropriate.

The fact that more nitrogen source and oxygen were obtained by free bacteria than immobilized bacteria prolonged the removal time by gel particle-immobilized bacteria (Yan et al., 2020). However, gel particles could provide stable micropores and protect cells from environmental changes and toxic substances (Hsieh et al., 2008; Hou et al., 2013). Zhang et al. (2021) prepared magnetic PVA-SA-diatomite composite carriers for immobilized microorganism and the highest $\mathrm{NH}_{4}{ }^{+}-\mathrm{N}$ removal rate reached $72.5 \%$ at $12 \mathrm{~h}$. It was found that the adsorptions of $\mathrm{NH}_{4}{ }^{+}-\mathrm{N}$ by non-magnetic ingredients and $\mathrm{Fe}_{3} \mathrm{O}_{4}$ contributed 21.2 and $25.5 \%$, respectively, and microorganism metabolism contributed $53.2 \%$. Immobilized degrading bacteria in PVA-SA hydrogel bead was also reported to remove polycyclic aromatic hydrocarbons (PAHs) and the removal efficiency was around 77\% in $96 \mathrm{~h}$ (Chen et al., 2021). Liu et al. (2019) investigated the effect of PVA-SA-cell cryogel bead-immobilized Bacillus sp. on the degradation of phenanthrene. The results indicated that the use of gel beads increased the number of adsorption sites to accelerate phenanthrene degradation.

\section{The Improvement of Ammonia Nitrogen Degradation With Biochar/Clay Composite Particle as Carrier}

On the basis of optimizing the immobilization method, BCCP was proposed as a carrier for Ochrobactrum sp. immobilization and the $\mathrm{NH}_{4}{ }^{+}-\mathrm{N}$ removal efficiency is demonstrated in Figure 4B. The strong adsorption of BCCP and gel made $\mathrm{NH}_{4}{ }^{+}$ $\mathrm{N}$ removal rate reach a high value on the first day. The efficiency of BC group (BCCP alone for adsorption as control group, $30.95 \%)$ was higher than that of SA/PVA-C group (29.94\%), which reflected that the adsorption performance of gel particle was lower than BCCP and gel hindered the adsorption process of BCCP. Until $168 \mathrm{~h}$, the removal efficiency was 34.35 and $31.55 \%$, respectively, and little change was discovered during the process. On the contrary, the degradation efficiency of free Ochrobactrum sp. was dilatory and only $6.87 \%$ was achieved at the first $24 \mathrm{~h}$, and increased to $84.82 \%$ at $168 \mathrm{~h}$. This phenomenon reflected that biodegradation played its advantages. For SA/PVABC-B group, the degradation efficiency of $\mathrm{NH}_{4}{ }^{+}-\mathrm{N}$ kept higher than free Ochrobactrum sp. during the reaction process and it was up to $79.39 \%$ at $168 \mathrm{~h}$, which exceeded $14.57 \%$ than free Ochrobactrum sp. group.

Compared with SA/PVA for microbial immobilization without adding BCCP, the results showed that BCCP as carrier to immobilize Ochrobactrum sp. could improve its degradation efficiency for $\mathrm{NH}_{4}{ }^{+}-\mathrm{N}$. Because the porous structure of BCCP provided a larger surface area and a greater number of holes, it could store more substrate and promote microbial growth. The porous structure of BCCPs provides larger specific surface area and more pores, and can store more matrix and promote microbial growth (Chen et al., 2016). 


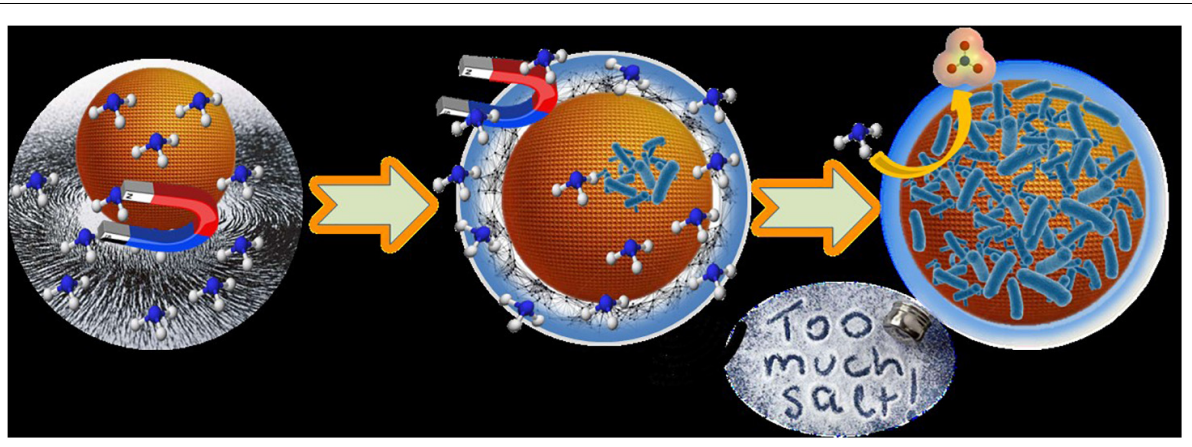

FIGURE 5 | $\mathrm{NH}_{4}{ }^{+}-\mathrm{N}$ removal mechanism by immobilization of Ochrobactrum sp. on BCCP.

\section{Ammonia Nitrogen Degradation Mechanism of Immobilizing Ochrobactrum sp. With Biochar/Clay Composite Particle}

Based on the aforementioned research results, the $\mathrm{NH}_{4}{ }^{+}-\mathrm{N}$ degradation mechanism of immobilizing Ochrobactrum sp. with BCCP is demonstrated in Figure 5. The potential mechanisms were summarized as follows: the physical adsorption of gel and BCCP promoted $\mathrm{NH}_{4}{ }^{+}-\mathrm{N}$ accumulation rapidly on the surface of BCCP, and provided more appropriate condition for microbial degradation. However, the gel covering on BCCP had a certain resistance for BCCP adsorption. Besides, the Ochrobactrum sp. embedded in gel could degrade the high concentration of $\mathrm{NH}_{4}{ }^{+}$$\mathrm{N}$ adsorbed on BCCP surface. The porosity of BCCP provides a necessary place for Ochrobactrum sp. growth and reproduction, and the adsorption driving force from BCCP promoted the biotransformation of Ochrobactrum sp.

\section{Effect of Salinity and Temperature on Nitrogen Removal \\ Effect of Salinity}

Microbial immobilization can resist the adverse environment. Salinity, as an important factor, affected the growth of microorganisms and osmotic pressure of cell membrane. In high-salinity environment, the growth of microorganisms was inhibited (Wang et al., 2017). The effect results of salinity on $\mathrm{NH}_{4}{ }^{+}-\mathrm{N}$ degradation are demonstrated in Figure 6A. For low salinity (lower than 5\%0), free Ochrobactrum sp. group kept high $\mathrm{NH}_{4}{ }^{+}-\mathrm{N}$ removal efficiency $(89.37-90.43 \%)$ and the degradation performance decreased to $36.24 \%$ when the salinity was up to $35 \%$. The phenomenon reflected that the nitrification process of Ochrobactrum sp. was inhabited under high salinity condition. However, the $\mathrm{NH}_{4}{ }^{+}-\mathrm{N}$ degradation efficiency was $69.32 \sim 72.31 \%$ in 0 and $5 \% 0$ experiment groups, and the immobilization with BCCP produced a marked enhancement performance that displayed $12.47 \%$ higher than free Ochrobactrum sp. when the salinity increased to $35 \%$. Gao et al. (2020) found that immobilized materials owned a protective effect on bacteria in environments with high salinity and bacterial growth was inhibited when the salinity was higher than $15 \%$. Bacteria needed to obtain additional energy from the substrate to maintain cell activity in a high-salinity environment, and they could gradually adapt to high salinity environments over time (Moussa et al., 2005; Ge et al., 2019).

\section{Effect of Temperature}

Temperature is another key factor affecting microbial growth and enzyme activity, and the low temperature resistance for

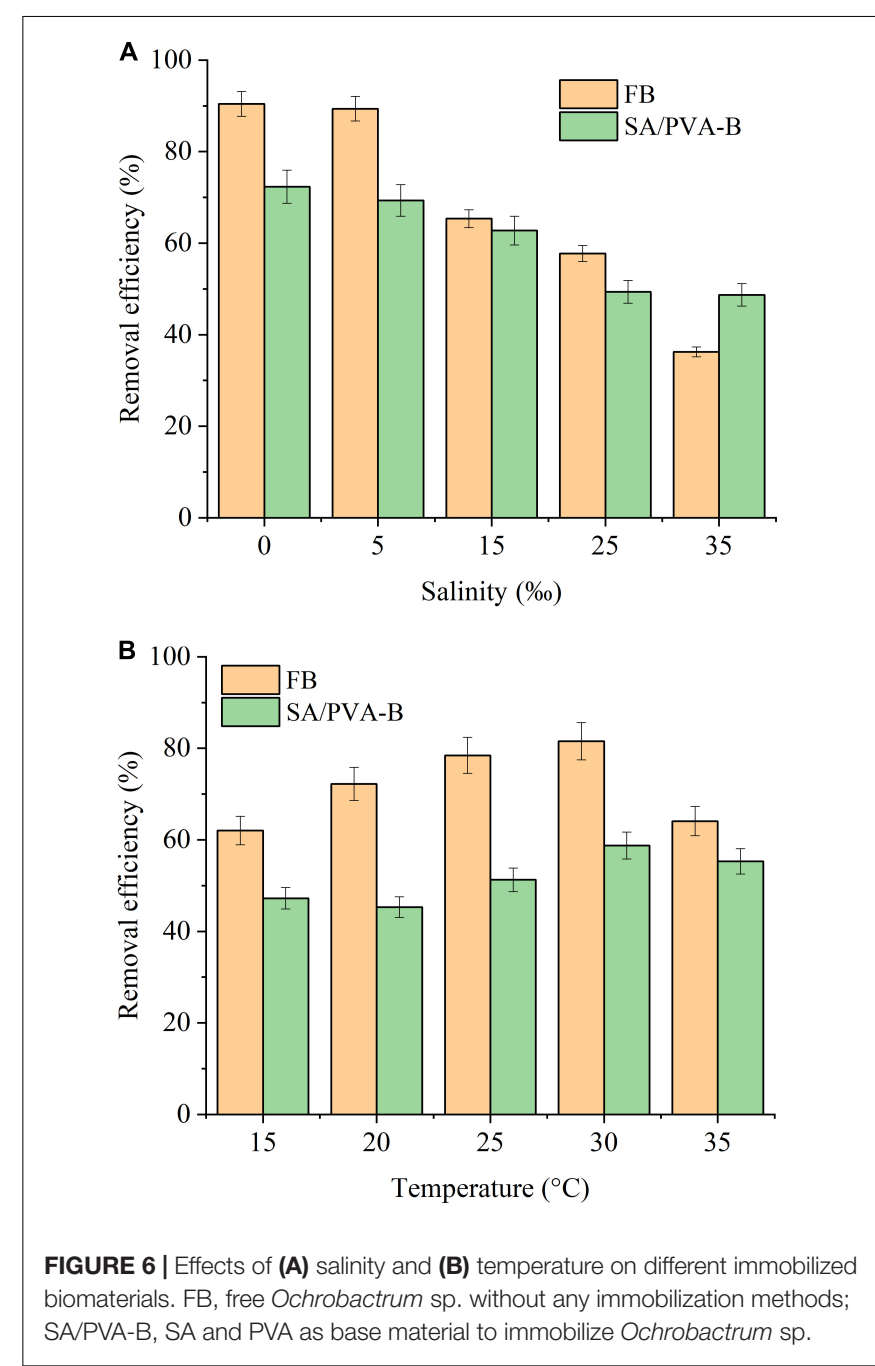


immobilized microorganisms is shown in Figure 6B. The $\mathrm{NH}_{4}{ }^{+}-\mathrm{N}$ removal efficiency of free or immobilized Ochrobactrum sp. groups increased with the temperature increasing from 15 to $30^{\circ} \mathrm{C}$, while the efficiency decreased rapidly at $35^{\circ} \mathrm{C}$. Compared with free bacteria group, microbial immobilization did not show its advantages, and its degradation efficiency was inferior to free Ochrobactrum sp. under different temperature conditions. For free bacteria group, $81 \%$ degradation efficiency was achieved at $30^{\circ} \mathrm{C}$, which was $20 \%$ more than immobilized Ochrobactrum sp. group. For AOB, the optimal temperature is $30^{\circ} \mathrm{C}$ and bacteria grow perfectly at this temperature (Huang et al., 2017). When the temperature was lower than the optimal temperature, it affected the enzymatic reaction of cells and limited the growth rate of bacteria (SerraMaia et al., 2016; Binnal and Babu, 2017; Huang et al., 2017; Manhaeghe et al., 2019). On the contrary, higher temperature could inactivate certain proteins in cell, reduced the activity of the microorganism, and even led to cell death (Ras et al., 2013; Serra-Maia et al., 2016; Nwoba et al., 2019). In this study, immobilized Ochrobactrum sp. did not play an effective role in resisting low temperature, but protected the Ochrobactrum sp. from the changes in salinity. The reason might be that as SA and PVA are the embedding materials of immobilized Ochrobactrum sp., the dense protective layer formed by them could buffer the salt concentration of microbial layer on the surface of BCCP, but could not block the impact of low temperature.

\section{CONCLUSION}

The optimum calcined parameters of CBBP were calcined temperature $400^{\circ} \mathrm{C}$, heating rate $20^{\circ} \mathrm{C} \mathrm{min}^{-1}$, and holding time $2 \mathrm{~h}$, and the composite particle owned better adsorption performance with $38.75 \% \mathrm{NH}_{4}{ }^{+}-\mathrm{N}$ removal efficiency and

\section{REFERENCES}

Atcharaporn, Y., Pinit, K., Nichada, J., Jitrin, C., Nontipa, S., and Andrew, J. (2020). Simultaneous manganese adsorption and biotransformation by Streptomyces violarus strain $\mathrm{SBP}_{1}$ cell-immobilized biochar. Sci. Total. Environ. 713:136708. doi: 10.1016/j.scitotenv.2020.136708

Atkinson, C. J., Fitzgerald, J. D., and Hipps, N. A. (2010). Potential mechanisms for achieving agricultural benefits from biochar application to temperate soils: a review. Plant. Soil. 337, 1-18. doi: 10.1007/s11104-010-0464-5

Binnal, P., and Babu, P. N. (2017). Optimization of environmental factors affecting tertiary treatment of municipal wastewater by chlorella protothecoides in a lab scale photobioreactor. J. Water Process. Eng. 17, 290-298. doi: 10.1016/j.jwpe. 2017.05.003

Chen, L., Chen, X. L., Zhou, C. H., Yang, H. M., Ji, S. F., Tong, D. S., et al. (2017). Environmental-friendly montmorillonite-biochar composites: Facile production and tunable adsorption-release of ammonium and phosphate. J. Clean. Prod. 156, 648-659. doi: 10.1016/j.jclepro.2017.04.050

Chen, W., Zhang, H., Zhang, M., Shen, X., Zhang, X., Wu, F., et al. (2021). Removal of PAHs at high concentrations in a soil washing solution containing TX100 via simultaneous sorption and biodegradation processes by immobilized degrading bacteria in PVA-SA hydrogel beads. J. Hazard. Mater. 410:124533. doi: 10.1016/j.jhazmat.2020.124533

Chen, X., Wu, L., Liu, F., Luo, P., Zhuang, X., Wu, J., et al. (2018). Performance and mechanisms of thermally treated bentonite for enhanced phosphate removal
$0.492 \mathrm{mg} \mathrm{g}^{-1}$ adsorption capacity. SA/PVA was more suitable as embedding material and jointed with BCCP (carrier) adsorbing $\mathrm{NH}_{4}{ }^{+}-\mathrm{N}$, which was then degraded by Ochrobactrum sp. with the degradation efficiency of $79.39 \%$ at $168 \mathrm{~h}$. Immobilizing Ochrobactrum sp. could protect the strain from high salt concentration to achieve the exceeding degradation efficiency than free bacteria; however, it could not block the impact of low temperature.

\section{DATA AVAILABILITY STATEMENT}

The original contributions presented in the study are included in the article/supplementary material, further inquiries can be directed to the corresponding author/s.

\section{AUTHOR CONTRIBUTIONS}

PS contributed to the data curation, methodology, and writingoriginal draft, review, and editing. $\mathrm{XH}$ designed all the experiments, and revised and examined the manuscript. YX reviewed and edited the manuscript. WLD, JY, and JB contributed to the data curation and investigation. WYD interpreted the data and provided the resources. All authors read and approved the final manuscript.

\section{FUNDING}

This work was supported by the Special Project of Guangxi Science and Technology Base and Talent (GUIKE AD20297065), and the National Natural Science Foundation of China (U20A20103).

from wastewater. Environ. Sci. Pollut. R. 25, 15980-15989. doi: 10.1007/s11356018-1794-8

Chen, Y., Yu, B., Lin, J., Naidu, R., and Chen, Z. (2016). Simultaneous adsorption and biodegradation (SAB) of diesel oil using immobilized acinetobacter venetianus on porous material. Chem. Eng. J. 289, 463-470. doi: 10.1016/j.cej. 2016.01.010

Feng, J., Ding, Y., Guo, Y., Li, X., and Li, W. (2013). Calcination temperature effect on the adsorption and hydrogenated dissociation of $\mathrm{CO}_{2}$ over the $\mathrm{NiO} / \mathrm{MgO}$ catalyst. Fuel. 109, 110-115. doi: 10.1016/j.fuel.2012.08.028

Feng, J., Liu, Y., Zhang, L., Zhu, J., Chen, J., Xu, H., et al. (2020). Effects of calcination temperature on organic functional groups of $\mathrm{TiO}_{2}$ and the adsorption performance of the $\mathrm{TiO}_{2}$ for methylene blue. Sep. Sci. Technol. 55, 672-683. doi: 10.1080/01496395.2019.1574822

Gao, Y., Wang, X., Li, J., Lee, C. T., Ong, P. Y., Zhang, Z., et al. (2020). Effect of aquaculture salinity on nitrification and microbial community in moving bed bioreactors with immobilized microbial granules. Bioresour. Technol. 297:122427. doi: 10.1016/j.biortech.2019.122427

Ge, C. H., Dong, Y., Li, H., Li, Q., Ni, S. Q., Gao, B., et al. (2019). Nitritationanammox process-A realizable and satisfactory way to remove nitrogen from high saline wastewater. Bioresour. Technol. 275, 86-93. doi: 10.1016/j.biortech. 2018.12.032

Hina, K., Hedley, M., Camps-Arbestain, M., and Hanly, J. (2015). Comparison of pine bark, biochar and zeolite as sorbents for $\mathrm{NH}_{4}{ }^{+}-\mathrm{N}$ removal from Water. Clean Soil Air Water. 43, 86-91. doi: 10.1002/clen.201300682 
Hou, D., Shen, X., Luo, Q., He, Y., Wang, Q., and Liu, Q. (2013). Enhancement of the diesel oil degradation ability of a marine bacterial strain by immobilization on a novel compound carrier material. Mar. Pollut. Bull. 67, 146-151. doi: 10.1016/j.marpolbul.2012.11.021

Hsieh, F. M., Huang, C., Lin, T. F., Chen, Y. M., and Lin, J. C. (2008). Study of sodium tripolyphosphate-crosslinked chitosan beads entrapped with pseudomonas putida for phenol degradation. Process. Biochem. 43, 83-92. doi: 10.1016/j.procbio.2007.10.016

Huang, X., Bai, J., Li, K., Zhao, Y., Tian, W., and Hu, C. (2020). Preparation of clay/biochar composite adsorption particle and performance for ammonia nitrogen removal from aqueous solution. J. Ocean. U. China. 19, 729-739. doi: 10.1007/s11802-020-4150-9

Huang, X., Bai, J., Li, K. R., Zhao, Y. G., Tian, W. J., and Dang, J. J. (2017). Characteristics of two novel cold- and salt-tolerant ammonia-oxidizing bacteria from Liaohe Estuarine Wetland. Mar. Pollut. Bull. 114, 192-200. doi: 10.1016/j. marpolbul.2016.08.077

Kar, S., and Equeenuddin, S. M. (2019). Adsorption of chromium (VI) onto natural mesoporous goethite: Effect of calcination temperature. Groundwater Sustain. Devel. 2019:100250. doi: 10.1016/j.gsd.2019.100250

Kong, W., Zhang, M., Liu, Y., Gou, J., Wei, Q., and Shen, B. (2021). Physicochemical characteristics and the adsorption of ammonium of biochar pyrolyzed from distilled spirit lees, tobacco fine and Chinese medicine residues. J. Anal. Appl. Pyrolysis. 156:105148. doi: 10.1016/j.jaap.2021.105148

Li, R., Wang, J. J., Gaston, L. A., Zhou, B., Li, M., Xiao, R., et al. (2018). An overview of carbothermal synthesis of metal-biochar composites for the removal of oxyanion contaminants from aqueous solution. Carbon. 129, 674-687. doi: 10.1016/j.carbon.2017.12.070

Li, S., Harris, S., Anandhi, A., and Chen, G. (2019). Predicting biochar properties and functions based on feedstock and pyrolysis temperature: A review and data syntheses. J. Clean. Prod. 215, 890-902. doi: 10.1016/j.jclepro.2019.01.106

Lin, K., Pan, J., Chen, Y., Cheng, R., and Xu, X. (2009). Study the adsorption of phenol from aqueous solution on hydroxyapatite nanopowders. J. Hazard. Mater. 161, 231-240. doi: 10.1016/j.jhazmat.2008.03.076

Lin, Q., Ishikawa, T., Akoh, R., Yang, F., and Zhang, S. (2016). Soil salinity reduction by river water irrigation in a reed field: A case study in Shuangtai Estuary Wetland. Northeast China. Ecol. Eng. 89, 32-39. doi: 10.1016/j.ecoleng. 2016.01.003

Liu, Q., Yao, X., Cheng, H., and Frost, R. L. (2012). An infrared spectroscopic comparison of four chinese palygorskites. Spectrochim. Acta A. 96, 784-789. doi: 10.1016/j.saa.2012.07.025

Liu, S.-H., Zeng, Z.-T., Niu, Q.-Y., Xiao, R., Zeng, G.-M., Liu, Y., et al. (2019). Influence of immobilization on phenanthrene degradation by Bacillus sp. P1 presence Cd (II). Sci. Total. Environ. 655, 1279-1287. doi: 10.1016/j.scitotenv. 2018.11.272

Mahdi, Z., Qiming, J. Y., and El Hanandeh, A. (2018). Removal of lead(II) from aqueous solution using date seed-derived biochar: batch and column studies. Appl. Water. Sci. 8:181. doi: 10.1007/s13201-018-0829-0

Mandal, S., and Mayadevi, S. (2008). Adsorption of fluoride ions by $\mathrm{Zn}-\mathrm{Al}$ layered double hydroxides. Appl. Clay Sci. 40, 54-62. doi: 10.1016/j.clay.2007.07.004

Manhaeghe, D., Michels, S., Rousseau, D. P., and Van Hulle, S. W. (2019). A semimechanistic model describing the influence of light and temperature on the respiration and photosynthetic growth of Chlorella vulgaris. Bioresour. Technol. 274, 361-370. doi: 10.1016/j.biortech.2018.11.097

Moussa, M. S., Hooijmans, C. M., Lubberding, H. J., Gijzen, H. J., and Van Loosdrecht, M. C. M. (2005). Modelling nitrification, heterotrophic growth and predation in activated sludge. Water Res. 39, 5080-5098. doi: 10.1016/j.watres. 2005.09.038

Nwoba, E. G., Parlevliet, D. A., Laird, D. W., Alameh, K., and Moheimani, N. R. (2019). Moheimani. Light management technologies for increasing algal photobioreactor efficiency. Algal Res. 39:101433. doi: 10.1016/j.algal.2019. 101433

Ojeda-López, R., Ramos-Sánchez, G., García-Mendoza, C., Cs Azevedo, D., Guzmán-Vargas, A., and Felipe, C. (2021). Effect of calcination temperature and chemical composition of pan-derived carbon microfibers on $\mathrm{N}_{2} . \mathrm{CO}_{2}$, and $\mathrm{CH}_{4}$ adsorption. Materials. 14:3914. doi: 10.3390/ma14143914
Ras, M., Steyer, J. P., and Bernard, O. (2013). Temperature effect on microalgae: a crucial factor for outdoor production. Rev. Environ. Sci. Biotechnol. 12, 153-164. doi: 10.1007/s11157-013-9310-6

Reddy, S., and Osborne, J. W. (2020). Biodegradation and biosorption of reactive red 120 dye by immobilized pseudomonas guariconensis: Kinetic and toxicity study. Water Environ. Res. 92, 1230-1241. doi: 10.1002/wer.1319

Serra-Maia, R., Bernard, O., Gonçalves, A., Bensalem, S., and Lopes, F. (2016). Influence of temperature on chlorella vulgaris growth and mortality rates in a photobioreactor. Algal Res. 18, 352-359. doi: 10.1016/j.algal.2016. 06.016

Sun, Q., Hu, X., Zheng, S., Sun, Z., Liu, S., and Li, H. (2015). Influence of calcination temperature on the structural, adsorption and photocatalytic properties of $\mathrm{TiO}_{2}$ nanoparticles supported on natural zeolite. Powder Technol. 274, 88-97. doi: 10.1016/j.powtec.2014.12.052

Vu, T. M., Doan, D. P., Van, H. T., Nguyen, T. V., Vigneswaran, S., and Ngo, H. H. (2017). Removing ammonium from water using modified corncob-biochar. Sci. Total. Environ. 579, 612-619. doi: 10.1016/j.scitotenv.2016.11.050

Wang, Y., Chen, J., Zhou, S., Wang, X., Chen, Y., Lin, X., et al. (2017). 16S rRNA gene high-throughput sequencing reveals shift in nitrogen conversion related microorganisms in a CANON system in response to salt stress. Chem. Eng. J. 317, 512-521. doi: 10.1016/j.cej.2017.02.096

Wang, Y., Tian, W., Wu, C., Bai, J., and Zhao, Y. (2016). Synthesis of coal cinder balls and its application for CODCr and ammonia nitrogen removal from aqueous solution. Desalin. Water. Treat. 57, 21781-21793. doi: 10.1080/ 19443994.2015.1130653

Yakkala, K., Yu, M. R., Roh, H., Yang, J. K., and Chang, Y. Y. (2013). Buffalo weed (Ambrosia trifida L. var. trifida) biochar for cadmium (II) and lead (II) adsorption in single and mixed system. Desalin. Water. Treat. 51, 7732-7745. doi: 10.1080/19443994.2013.792546

Yan, H., Han, Z., Zhao, H., Pan, J., Zhao, Y., Tucker, M. E., et al. (2020). The bio-precipitation of calcium and magnesium ions by free and immobilized Lysinibacillus fusiformis DB1-3 in the wastewater. J. Clean. Prod. 252:119826. doi: 10.1016/j.jclepro.2019.119826

Yan, S., Huo, W., Yang, J., Zhang, X., Wang, Q., Wang, L., et al. (2018). Green synthesis and influence of calcined temperature on the formation of novel porous diatomite microspheres for efficient adsorption of dyes. Powder Technol. 2018, 260-269. doi: 10.1016/j.powtec.2018.01.090

Yang, Y., and Chow, C. L. (2019). Tal cracking prediction of frameless glazing exposed to radiant fluxes increasing with height. Fire. Mater. 43, 747-756. doi: 10.1002/fam.2734

Zhang, L., Zhang, H., Guo, W., and Tian, Y. (2013). Sorption characteristics and mechanisms of ammonium by coal by-products: slag, honeycomb-cinder and coal gangue. Int. J. Environ. Sci. Technol. 10, 1309-1318. doi: 10.1007/s13762012-0168-X

Zhang, Y., Yu, Z., Hu, Y., Song, C., Li, F., He, W., et al. (2021). Immobilization of nitrifying bacteria in magnetic PVA-SA-diatomite carrier for efficient removal of NH4+-N from effluents. Environ. Technol. Inno. 22:101407. doi: 10.1016/j. eti.2021.101407

Conflict of Interest: The authors declare that the research was conducted in the absence of any commercial or financial relationships that could be construed as a potential conflict of interest.

Publisher's Note: All claims expressed in this article are solely those of the authors and do not necessarily represent those of their affiliated organizations, or those of the publisher, the editors and the reviewers. Any product that may be evaluated in this article, or claim that may be made by its manufacturer, is not guaranteed or endorsed by the publisher.

Copyright (c) 2022 Sun, Huang, Xing, Dong, Yu, Bai and Duan. This is an open-access article distributed under the terms of the Creative Commons Attribution License (CC BY). The use, distribution or reproduction in other forums is permitted, provided the original author(s) and the copyright owner(s) are credited and that the original publication in this journal is cited, in accordance with accepted academic practice. No use, distribution or reproduction is permitted which does not comply with these terms. 